\title{
Novel Genomic Approach to the Arrhytmogenic Sudden Cardiac Death
}

\author{
Maria Brion, Beatriz Sobrino, Alejandro Blanco-Verea, \\ Montserrat Santori, Rocio Gil and Angel Carracedo \\ Genomic Medicine Group, IDIS, CIBERER-University of Santiago, FPGMX \\ Spain
}

\section{Introduction}

Unfortunately, most of the common diseases in cardiology do not show traditional Mendelian genetics, they usually are complex genetic diseases resulting from the combination of multiple heritable and environmental factors. However, one of the cardiology dysfunction that can affect apparently healthy young adults or with any previous heart disease, such as sudden cardiac death (SCD), could be the first symptom of a Mendelian disease such as cardiomyopathies or channelopathies.

In many of the SCD cases, especially in case of young people, the cause of death cannot be explained neither after autopsy nor after laboratory tests. Inherited heart diseases such as hypertrophic cardiomyopathy ( $\mathrm{HCM})$, arrhythmogenic right ventricular cardiomyopathy (ARVC) and primary electrical diseases such as long QT syndrome (LQTS), Brugada syndrome $(\mathrm{BrS})$ or catecholaminergic polymorphic ventricular tachycardia (CPVT), are the main cause of death in young adults with no previous clinical history. Most often these inherited cardiac disorders give rise to lethal ventricular arrhythmias and show an autosomal dominant mode of inheritance.

Genetic screening of the genes described as implicated in the different pathologies may help to determine the cause of death and to evaluate the potential risk of the relatives. Today we know which are the main causes of sudden cardiac death in young adults and we also know which are the genes responsible of these diseases in a high percentage of cases. The aim of this article is to present to the reader the estate of the art of the use of the new next generation sequencing technologies for the study of arrhythmogenic sudden cardiac deaths. We will discuss the different available technologies, and the different applications:

Candidate gene resequencing. We will describe the interesting genes to be studied and the different strategies available for their enrichment and sequencing

Whole exome resequencing. We will describe the application of this approach to those cases were we need to look for new genes.

\section{Inherited arrhythmogenic diseases}

There are various arrhythmogenic disorders, with different electrocardiographic patterns, which are not always present or are not evident in carriers of mutations implicated in the 
pathology. In general these are diseases with low penetrance so the genetic study is of great importance in patients with personal or family history of sudden cardiac death.

The term inherited arrhythmogenic diseases typically includes cardiac diseases caused by mutations in ion channels and ion channel-controlling proteins such as the long-QT syndrome (LQTS), the short QT syndrome (SQTS), the Brugada syndrome (BrS) and catecholaminergic polymorphic ventricular tachycardia (CPVT). Ion channels are integral membrane proteins that regulate the flow of ions across the cell membrane. They consist of multimeric units generally encoded by different genes. The a subunit forms the pore and mediates ion current, while the $\beta$ subunits are regulatory. Defects in these channels due to mutations in genes that encode proteins, or mutations in proteins associated with these channels may lead to an electrical disturbance in the heart linked to the development of channelopathies.

\subsection{Long QT syndrome}

The Long QT Syndrome (LQTS) is characterized by prolongation of the QT interval on the electrocardiogram, which indicates ventricular repolarisation unusually long, due either to a decrease in the $\mathrm{K}^{+}$flow of repolarisation or to a delayed entry of $\mathrm{Na}^{+}$into the myocyte.

The estimated incidence is between 1:2000 -1:5000 people (Hedley et al., 2009), and its penetrance is variable, ranging from sub clinical phenotypes with a QT interval at the limit, without arrhythmias or syncope (Napolitano et al., 2005; Priori et al., 1999; Vicent et al., 1992) to sudden cardiac death, being a major cause of sudden death in young people. To determine wheter the QT interval is prolonged the corrected QT interval (QTc) is used, which is calculated using the Bazzet formula QTc $=$ QT $/ \sqrt{ }$ RR (Bazzet et al., 1920) Are considered abnormally prolonged QTc values when exceeding $440 \mathrm{~ms}$ in men and those over $460 \mathrm{~ms}$ in women (values corrected for heart rate). It is estimated that a patient with a QTc interval of $550 \mathrm{~ms}$ has a $63 \%$ higher risk of suffering a cardiac event that an individual with a value of QTc interval of $450 \mathrm{~ms}$. (Zareba et al., 2008).

The LQTS shows a congenital form of the disease in about $85 \%$ of cases and a sporadic form which corresponds to 15\% [85]. There is also an acquired form of QT prolongation caused mainly by drugs, both cardiac (e.g. antiarrhythmics) and other medications (e.g. antidepressants) or derived from an electrolyte imbalance. The congenital form shows two basic patterns of inheritance, one autosomal dominant called Romano-Ward syndrome and another autosomal recessive known as Jervell Lange-Nielsen syndrome, which presents with congenital deafness. To date 12 genes have been described in the pathology. The most common are genes that encode $\mathrm{K}+$ channels, KCNQ1, KCNH2, which represent about 40$55 \%$ and $35-45 \%$ of cases respectively, and the SCN5A gene coding for $\mathrm{Na}+$ channels which represents a $2-8 \%$ of cases (Hedley et al., 2009). The involvement of each of these genes leads to defined clinical phenotypes, so KCNQ1 gene leads to LQTS type 1 (LQT1), KCNH2 causes LQTS type 2 (LQT2) and SCN5A leads to LQTS3 (LQT3).

\subsection{Short QT syndrome}

The short QT syndrome (SQTS) has been recognized as a clinical entity characterized recently by a shortened QT interval that can lead to arrhythmias and sudden cardiac death (Gussak et al., 2000). Although there is no established consensus, it is accepted that a value between $320 \mathrm{~ms}$ and $340 \mathrm{~ms}$ are considered short (although it could be considered normal $340 \mathrm{~ms}$ ) if there is a history of cardiac symptoms such as syncope or aborted sudden death. Nevertheless, as in LQTS, the transition zone of normal QT intervals to pathological intervals is difficult to establish (Schimpf et al., 2007). 
In SQTS, mutations in genes encoding $\mathrm{K}+$ channels: $\mathrm{KCNH} 2, \mathrm{KCNJ} 2$, and $\mathrm{KCNQ} 1$, cause a gain of function of these channels and give rise to SQTS1, SQTS2and SQTS3 respectively. However, mutations in genes encoding a and $\beta 2$ subunits of the Cav1.2 channel, the CACNB2 and CACNA1C genes, cause loss of function of these channels and give rise to SQTS4 and SQTS5 phenotype respectively (Hedley et al., 2009).

\subsection{Brugada syndrome}

Brugada Syndrome (BrS) is characterized by ST segment elevation in right precordial leads (V1-V3) of the electrocardiogram and can also be associated with an increase in PR interval and bundle branch block. Penetrance is also variable, and can trigger polymorphic ventricular tachycardia and / or ventricular fibrillation and sudden death. The distribution and incidence of this disease is difficult to determine because it is a syndrome recently described and because electrocardiographic manifestations are not always present. Campuzano et al. (2010) estimate a prevalence of approximately 35/100000 persons / year and they say that, although symptoms usually develop around the age of 40 , sudden death can affect individuals of any age. They estimate sudden death affects $75 \%$ of the affected males, and between 20 and $50 \%$ of the affected people have a family history of sudden death.

The dominant pattern of inheritance is autosomal dominant with expression probably age dependent and incomplete penetrance. Today we have described more than 100 mutations in 7 different genes that give rise to the 7 types of BrS. These genes encode proteins of both $\mathrm{Na}+$ channels and other ion channels. The mutations affect the proper development of phases 1 and 2 of the cardiac action potential (Hedley et al., 2009b). It is estimated that 20$25 \%$ of BrS patients show mutations in the SCN5A gene (Schott et al., 1999), which also represents $5-10 \%$ of mutations found in cases of sudden cardiac death in adults and children (Hedley et al., 2009b) .

\subsection{Catecholaminergic polymorphic ventricular tachycardia}

Catecolaminergic polymorphic ventricular tachycardia (CPVT) occurs with a characteristic pattern of bidirectional or polymorphic tachycardia related to stress without structural cardiac abnormalities (Coumel et al., 1978). These clinical manifestations often occur during childhood and adolescence.

The CPVT has two modes of inheritance: autosomal dominant and recessive. The autosomal dominant form is caused by mutations in the gene encoding the ryanodine receptor RyR2, which is a large protein that forms the calcium release channel in sarcoplasmic reticulum. The recessive form of the disease is caused by mutations in the cardiac isoform calciquestrina gene (CASQ2), which binds to the ryanodine receptor and participates in the control of excitation-contraction (Ylänen et al., 2010). The steps of the molecular pathogenesis of CPVT are not entirely clear, but Mutations of the two interacting proteins, RyR2 and CASQ2, seem to result in inadequately controlled Ca2+ bursts into the sarcoplasm, with concomitant risk of delayed afterdepolarizations and triggered arrhythmia.

\section{Genetic screening of arrhythmogenic diseases}

The importance of knowing the molecular substrate in patients with inherited cardiac channelopathies is recognized and highlighted in the guidelines for the prevention of SCD developed by the American Heart Association, the American College of Cardiology, and the 
European Society of Cardiology (Zipes et al., 2006). Screening for mutations in genes that encode cardiac ion channels associated with LQTS, SQTS, BrS, and CPVT is primarily sought in clinically affected patients to tailor risk stratification and management and to further identify family members (Priori et al., 2002a, b, 2003). However, genetic analysis is not yet available at most clinical centres and it is still mainly performed in finite research laboratories.

Our present understanding of human inherited arrhythmia diseases has become increasingly complex. Several clinical syndromes have been identified as human inherited arrhythmia diseases and at least 21 genes are known to cause these diseases. These genes and the associated syndromes are given in Table 1. Mutations associated with inherited arrhythmia syndromes occur in ion channel pore-forming proteins, associating subunit proteins and channel interacting proteins , $\mathrm{Ca} 2+$ handling proteins, components of the ion cannel macromolecular complex, and regulatory pathways. Although most inherited arrhythmia syndromes are rare clinical findings, sometimes with just a single family described.

Several studies have been published trying to determine the effectiveness of genetic screening (Bai et al., 2009; Kapplinget et al., 2009) in terms of efficiency and cost. Bay et al. (2009) showed that the current cost of genetic testing for inherited cardiac channelopathies is reasonable for those who have a conclusive diagnosis and that these patients should have priority access to genetic screening (Fuster et al., 2008) However, until now these studies were limited by two main drawbacks, the reduced effectiveness of the techniques of genetic determination employed and the high cost of the same.

\begin{tabular}{|c|c|c|c|c|c|c|}
\hline Gen & Symbol & Locus & CPVT & LQTS & SQTS & BrS \\
\hline A kinase anchor protein (yotiao) 9 & AKAP9 & $7 q 21-q 22$ & & $x$ & & \\
\hline ankyrin 2 & ANK2 & $4 q 25-q 27$ & & $x$ & & \\
\hline calcium channel, voltage-dependent, L type, alpha $1 \mathrm{C}$ subunit & CACNA1C & $12 \mathrm{p} 13.3$ & & $x$ & $x$ & $\mathrm{x}$ \\
\hline calcium channel, voltage-dependent, beta 2 subunit & CACNB2 & $10 \mathrm{p} 12$ & & & $\mathrm{x}$ & $x$ \\
\hline calsequestrin 2 & CASQ2 & 1p13.3-p11 & $x$ & & & \\
\hline caveolin 3 & CAV3 & $3 \mathrm{p} 25$ & & $x$ & & \\
\hline glycerol-3-phosphate dehydrogenase 1-like & GPD1L & $3 \mathrm{p} 22.3$ & & & & $\mathrm{x}$ \\
\hline hyperpolarization activated cyclic nucleotide-gated potassium channel 4 & $\mathrm{HCN} 4$ & $15 q 24.1$ & & & & $x$ \\
\hline potassium voltage-gated channel, Isk-related family, member 1 & KCNE1 & $21 \mathrm{q} 22.12$ & & $x$ & & \\
\hline potassium voltage-gated channel, Isk-related family, member 2 & KCNE2 & $21 \mathrm{q} 22.12$ & & $x$ & & \\
\hline potassium voltage-gated channel, Isk-related family, member 3 & KCNE3 & $11 \mathrm{q} 13.4$ & & & & $x$ \\
\hline potassium voltage-gated channel, subfamily $\mathrm{H}$, member 2 & $\mathrm{KCNH} 2$ & $7 \mathrm{q} 36.1$ & & $x$ & $x$ & \\
\hline potassium inwardly-rectifying channel, subfamily J, member 2 & $\mathrm{KCNJ} 2$ & $17 \mathrm{q} 24.3$ & & $x$ & $x$ & \\
\hline potassium inwardly-rectifying channel, subfamily J, member 5 & KCNJ5 & $11 \mathrm{q} 24$ & & $x$ & & \\
\hline potassium voltage-gated channel, KQT-like subfamily, member 1 & KCNQ1 & $11 \mathrm{p} 15.5$ & & $x$ & $x$ & \\
\hline ryanodine receptor 2 & RYR2 & $1 \mathrm{q} 43$ & $\mathrm{x}$ & & & \\
\hline sodium channel, voltage-gated, type I, beta & SCN1B & $19 \mathrm{q} 13,1$ & & & & $\mathrm{x}$ \\
\hline sodium channel, voltage-gated, type III, beta & SCN3B & $11 \mathrm{q} 23,3$ & & & & $x$ \\
\hline sodium channel, voltage-gated, type IV, beta & SCN4B & $11 \mathrm{q} 23.3$ & & $x$ & & \\
\hline sodium channel, voltage-gated, type $\mathrm{V}$, alpha subunit & SCN5A & $3 p 21$ & & $x$ & & $\mathrm{x}$ \\
\hline syntrophin, alpha 1 & SNTA1 & $20 \mathrm{q} 11.2$ & & $x$ & & \\
\hline
\end{tabular}

Table 1. Genes related to arrhythmogenic sudden cardiac death

Today, with the development of the next generation sequencing strategies, these two problems are being overcome, so that on one hand, we managed to sequence as many genes as we want, detecting both, genetic variants already described and new variants not yet known; and on the other hand, we have significantly reduced the cost of each genetic screening and we hope that this reduction will still see increased in the future days.

The new next generation sequencing technologies are allowing us sequencing large number of DNA fragments or genes, using target resequencing strategies, in a fast, reliable and 
effective way. The selection of the genes will depend on the researcher's own interests, so that in our case, we could focus on those genes previously described as involved in arrhythmogenic heart diseases or we can make the sequencing of all genes and search exome mutations also in genes that have not previously been associated with the pathology. If we consider the aforementioned 21 genes as candidate genes to be sequenced, It would involve the sequencing of approximately 400 exons, accounting around 120.000 base pairs of coding DNA. This work, in terms of time and cost of each analysis represents a major handicap for the routine work of many small laboratories dedicated to genetic diagnosis of these pathologies. An indicative example of this type of analysis is the Familion test for Long QT syndrome (Kapplinger et al., 2009), a bidirectional DNA sequencing-based assay that comprises analysis of 73 polymerase chain reaction (PCR) amplicons to analyse the 3 major LQTS-susceptibility genes (KCNQ1 [LQT1], KCNH2 [LQT2], SCN5A [LQT3]) along with 2 minor genes (KCNE1 [LQT5] and KCNE2 [LQT6]). Kapplinger et al (2009) evaluated the Familion Test in 2500 unrelated LQTS cases and they found 903 positive genetic tests describing 562 putative mutations absent in 2600 reference alleles. They reported that despite the passage of 14 years since the first LQTS-causative mutations were discovered, still one-third of the mutations being discovered today are novel; therefore, this study is further evidence of the need for genetic screening strategies that allow us to detect both known mutations and new genetic variants, such as the sequencing. In addition, the study highlights the need for functional studies providing evidence on the possible pathogenicity for new genetic variants that are being described. Here we describe the implementation of a new research strategy using next generation sequencing, that allows the simultaneous study of the sequence of all the genes described in relation to arrhythmogenic disorders at risk of sudden cardiac death (candidate gene approach), or the study of the complete sequence of the human exome (whole exome approach), searching for genetic variants both in genes previously associated with sudden cardiac death and in new genes whose involvement in the fatal event is currently unknown

\section{Next generation sequencing}

Capillary electrophoresis based in Sanger sequencing is the technology widely used for analyzing genes involves in different pathologies. However, over the past five years, Next Generation Sequencing (NGS) technologies have became a reliable tool for massive parallel sequencing, overcoming the limitations in throughput and speed of capillary electrophoresis (Shendure \& Ji, 2008; Metzer, 2010; Glenn , 2011) .

On this chapter we will focus on commercially available platforms: 454 (Roche), Illumina Genome Analyzer (Illumina Inc.), SOLiD and Ion Torrent (Life Technologies) (Table 2).

The 454 Genome Sequencer (Roche) was the first NGS platform available (Margulies et al., 2005). Small fragments of DNA are attached onto the surface of beads and amplified via emulsion PCR. Millions of beads are deposited onto a picotitre plate. Sequencing is performed in parallel by pyrosequencing, where the incorporation of a nucleotide by a DNA polymerase results in the release of a pyrophosphate, which initiates a series of downstream reactions that ultimately produce light by a luciferase. The light can be correlated with the nucleotide incorporated, because the nucleotides are added following a sequential order.

The Illumina Genome Analyzer (Illumina Inc.) relies on bridge PCR on a glass slide to amplify small fragments of DNA. In this approach, forward and reverse PCR primers are attached to a solid surface, and as a consequence, amplification products originating from 
any single template molecule remain immobilized and clustered to a physical position on the array. Sequencing chemistry is based on sequencing by synthesis with reversible terminators (Fedurco et al., 2006; Turcatti et al., 2008), where all fluorescently labeled four nucleotides are added simultaneously to the flow cell channels, along with the polymerase, for incorporation into the oligo-primed cluster fragments obtained after bridge PCR.

The SOLiD system (Life Technologies) is based on sequencing by ligation and the use of two-base encoded probes (Valouev et al., 2008). A universal sequencing primer is hybridized to templates and a pool of fluorescently labelled octamer probes containing all possible combination of $\mathrm{A}, \mathrm{C}, \mathrm{G}$ and $\mathrm{T}$ at positions 1-5, interrogates the sequence of the unknown template on each bead. Only the probe homologous to the first five bases of the template will be ligated to the universal sequencing primer. Up to ten cycles of ligation, detection and cleavage record the colour at every fifth position. Templates for sequencing are prepared via emulsion PCR.

In the case of the Ion PGM Sequencer (Life Technologies), sequence data are obtained by directly sensing the ions produced by template-directed DNA polymerase synthesis using all natural nucleotides on the ion chip. The ion chip contains ion-sensitive, field-effect transistor-based sensors in 1.2 million wells, which allow parallel and simultaneous detection of independent sequencing reactions (Rothberg et al., 2011). As 454 and SOLiD, template preparation is performed by emulsion PCR. Unlike the other technologies where the throughput is determined by the equipment, the Ion PGM throughput is determined by the chip used for sequencing (Table 2)

Very promising NGS approaches are the ones based on single molecule sequencing like Helicos Biosciences (Harris et al., 2008) and Pacific Biosciences (Eid et al., 2009), where sequencing is performing directly on the DNA, avoiding any amplification step. However, these platforms are not commercially available so they are only mentioned.

\begin{tabular}{llll}
\hline \multicolumn{1}{c}{ Instrument } & \multicolumn{1}{c}{$\begin{array}{c}\text { Read length } \\
\text { (bp) }\end{array}$} & $\begin{array}{c}\text { Maximum } \\
\text { Throughput }\end{array}$ & Run time \\
\hline 454-GS Junior & 400 & $50 \mathrm{Mb}$ & $10 \mathrm{~h}$ \\
454-FLX+ & 700 & $900 \mathrm{Mb}$ & $23 \mathrm{~h}$ \\
\hline Illumina-MiSeq & $150+150$ & $>1 \mathrm{~Gb}$ & $27 \mathrm{~h}$ \\
Illumina-GAII & $150+150$ & $95 \mathrm{~Gb}$ & 14 days \\
Illumina-HiScanSQ & $100+100$ & $150 \mathrm{~Gb}$ & 11 days \\
Illumina-HiSeq1000 & $100+100$ & $300 \mathrm{~Gb}$ & 11 days \\
Illumina-HiSeq2000 & $100+100$ & $600 \mathrm{~Gb}$ & 11 days \\
\hline SOLiD-5500 & $75+35$ & $90 \mathrm{~Gb}$ & 7 days \\
SOLiD-5500xl & $75+35$ & $180 \mathrm{~Gb}$ & 7 days \\
\hline Ion PGM - 314 chip & 200 & $>10 \mathrm{Mb}$ & $2 \mathrm{~h}$ \\
Ion PGM - 316 chip & 200 & $>100 \mathrm{Mb}$ & $2 \mathrm{~h}$ \\
\hline
\end{tabular}

Table 2. Comparison of NGS platforms.

\section{Target resequencing strategies}

For some applications, it would be not necessary to sequence the whole genome, but sequence specific region or regions. This is the case of the study of: i) a disease phenotype previously mapped to a specific region of the genome, ii) candidate genes involve in a 
pathology or pathway, iii) whole exome. To reach these purposes it is necessary the combination of methods for targeted capture with massive parallel sequencing.

Methods for capturing the regions of interest are commercially available, but it is important to remind that, due to this field is in continuous and rapid evolution, before designing any experiment it will be necessary to check for latest approaches, in order to choose the more cost-effective strategy for each project (Turner et al., 2009; Mamanova et al., 2010).

Even considering the different capture strategies, the workflow for targeted resequencing for either candidate genes or exome sequencing is very similar. Genomic DNA is used to construct a library, which consists in small fragments of DNA flanqued by adaptors. Depending on the method used for capturing the regions of interest, the capture occurs before or after creating the library. Once the capture library is created, is clonally amplified followed by massive parallel sequencing.

During the process of capturing and library preparation it is possible to barcoding samples. This process enables the user to pool multiple samples per sequencing run, taking advantage of the high-throughput of the NGS platforms.

Capture strategies can be broadly grouped in two main groups, the first one is based on PCR, and the second one in the use of hybridization probes (Table 3).

1. PCR approaches:

When a specific region has been previously mapped, long-PCRs using high-fidelity polymerases are used to analyze large kilobase-sized contiguous intervals (Yeager et al., 2008).

Different strategies for amplified simultaneously hundreds of fragments of DNA have been developed over the last years. Access Array System (Fluidgm) uses a microfluidic chip with nanoliter scale chambers, where the simultaneous amplification of 48 different fragments in 48 samples is performed. By incorporating the adaptor sequences into the primer design the amplicon product is ready to go directly into clonal amplification (Voelkerding et al., 2010).

Microdroplet-PCR technology developed by RainDance involves the use of emulsion PCR in a microfluidic device, creating droplets of primers in oil solution. The primer droplets that are targeted to different regions of the genome merge with separate droplets that contain fragmented genomic DNA and PCR reagents. These mixed droplets are thermal cycled in a single tube. The encapsulation of microdroplet PCR reactions prevents possible primer pair interactions allowing an efficient simultaneous amplification of up to 20,000 targeted sequences (Tewhey et al., 2009).

Illumina and Life Technologies have followed similar strategies for capture regions for MiSeq and Ion PGM Sequencer, respectively. Illumina has launched the TrueSeq Custom Amplicon Kit for multiplex amplification of up to 384 amplicons per sample, and Life Technology has recently developed a multiplex PCR for amplified in a single tube up to 480 known as Ion AmpliSeq Cancer Panel. Currently, only the cancer panel is available, but it has been announced by the company that custom panels will be early available.

Halo Genomics has developed two different strategies based on amplification methods, Selector and HaloPlex. The first one, Selector Target Enrichment system is based on multiple displacement amplification. This strategy produces circular DNA that is amplified in a whole genome amplification reaction. The resulting high molecular DNA product is compatible with all next generation sequencing library preparation protocols. For achieving this, DNA sample is first fragmented using restriction 
enzymes, secondly the probe library is added and the probes hybridize with the targeted fragments. Each probe is an oligonucleotide designed to hybridize to both ends of a targeted DNA restriction fragment, thereby guiding the targeted fragments to form circular DNA molecules. The circular molecules are closed by ligation and then amplified. Next step is library preparation (Johansson et al., 2010).

In the case of HaloPlex technology, PCR products are ready for pooling and direct sequencing, it is not necessary to create the library after the capturing because the probes also contain a specific sequencing motif that is incorporated during the circularization. This motif allows the incorporation of specific adaptors and barcodes during the amplification. Currently, this product is optimized for Illumina.

2. Hybridization

Other strategy is capture by hybridization of specific probes complementary of the regions of interest. The first hybridization approaches were based on-array capture (Albert et al., 2007; Hodges et al., 2007; Ng et al., 2009). But to avoid the disadvantages of working with microarrays, currently methods are based in-solution capture. Fragment libraries are hybridized to biotinilated probes in solution and subsequently recovered with streptavidin-magnetic beads, amplified and sequence in the platform of choice (Gnirke et al., 2009; Bamshad., 2011).

All the vendors (Agilent, Nimblegen, Illumina and Life Technologies) offer kits either predesigned for specific application such as exome sequencing, cancer, etc or custom panels to be designed for the user (Table 3). There are different kits for different sizes of the region of interest that go from less than $100 \mathrm{~kb}$ to up $60 \mathrm{Mb}$.

\begin{tabular}{clcc}
\hline Approach & \multicolumn{1}{c}{ Method } & Kits $^{\mathbf{a}}$ & $\begin{array}{c}\text { NGS - } \\
\text { Compatibility }\end{array}$ \\
\hline \multirow{5}{*}{ PCR } & Long-PCR & 1 & $1,2,3,4$ \\
& Access Array System (Fluidigm) & 1 & $1,2,3,4$ \\
& Microdroplet PCR (Raindance) & 1,2 & $1,2,3,4$ \\
& AmpliSeq technology & $2 \mathrm{c}$ & 4 \\
& (Life Technologies) & 1 & 2 \\
& TrueSeq Amplicon Kit (Illumina) & 1 & 2 \\
& HaloPlex (Halo Genomics) & 1,2 & $1,2,3,4$ \\
\hline \multirow{3}{*}{ In-solution } & Selector (Halo Genomics) & 1,3 & 2,3 \\
hybridization & SureSelect (Agilent) & 1,3 & $1,2,3$ \\
& SeqCap EZ (Nimblegen) & 1,3 & 2 \\
& TrueSeq Enrichment Kit (Illumina) & 1,3 & 3,4 \\
\hline
\end{tabular}

a Custom (1), specific gene panel (ej. cancer panel) (2), exome panel (3)

b 454 (1), Illumina (2), SOLiD (3), Ion PGM Sequencer (4).

c Custom early available

Table 3. Capture methods for targeted resequencing.

\subsection{Candidate gene resequencing}

In dealing with arrhythmogenic diseases at risk of sudden cardiac death, we can analyze those genes previously associated with the pathologies that explain a high percentage of cases, variable according to the pathology (Hedley et al., 2009ab; Kapplinget et al., 2009). 
Therefore, as it was already used for SCD associated cardiomyoapties (Meder et al., 2011), the strategy with the arrhythmogenic diseases could be to capture the 21 genes mentioned above in Table 1 . As it is shown in table 3 , there are a great variety of strategies available. In addition, all commercially available kits have developed tools for designing specific primers or probes to capture the regions of interest.

For selecting both the capture method and the NGS platform many factors have to be evaluated: size of the region of interest, the coverage and accuracy needed, the number of samples and barcodes availability and DNA requirement. There is no an ideal method for all the situations.

\subsection{Whole exome resequencing}

The targeted resequencing of the subset of the genome that is protein coding is known as exome sequencing. This strategy is been a powerful approach for either identifying genes involve in Mendelian disorders or rare variants underlying the heritability of complex traits (Bamshad, 2011). Therefore, arrhythmogenic diseases such as the LQTS, the SQTS, the CPVT or the BrS, all genetic diseases with Mendelian inheritance, are appropriate candidates for this type of study.

All the vendors of in-solution hybridization methods have developed commercial kits for capturing whole exome. (Agilent, Illumina, LifeTechnologies, NimbleGen) (Table 3). Due to the throughput needed for obtaining enough coverage for variant calling, the platforms of choice for this application are Illumina GAII or superior and SOLiD 5500.

This approach has been successfully used since 2009 in at least 29 diseases, in which the genes involved in the disorders have been identified (Bamshad, 2011).

\section{Genetic variant versus mutation}

It should be kept in mind that this kind of genetic tests identifies the presence of a probable/possible arrythmogenic disease causing mutation for which the probability for pathogenesis and even the likelihood of sudden cardiac death is influenced by many factors, including rarity, conservation, topological location, co-segregation, functional studies, and so forth. According to Kapplinger et al. (2009), fewer than $25 \%$ of the previously published LQTS mutations have been characterized by heterologous expression studies to demonstrate the anticipated loss-of-function (LQT1 and LQT2) or gain-of-function (LQT3) conferred by the mutation. The rank of a new genetic variant detected in an afected individual as a pathogenic mutation must meet the following specifications:

a. The variant must disrupt either the open reading frame (i.e., missense, nonsense, insertion/deletion, or frame shift mutations) or the splice site (poly-pyrimidine tract, splice acceptor or splice donor recognition sequences). Considering the acceptor splice site as the 3 intronic nucleotides preceding an exón (designated as IVS-1, -2, or -3) and the donor splice site as the first 5 intronic nucleotides after an exon (designated as IVS+1, +2, +3, +4, or +5) (Rogan et al., 2003).

b. The variant must be absent in a representative cohort of healthy unrelated individuals with a minimum of 200 individuals and 400 alleles with a common population origin.

c. The variant must have been absent in all published databases listing the common polymorphisms in the studied genes and previously published reports or compendia of rare control variants. 
Many of the possible new genetic variants described, although they meet the requirements listed above, may not have any pathogenic effect and the only real way to check would be through functional studies that prove this effect. Due to the difficulty in performing such studies in many of the functional proteins involved, during the last years several "in silico" tools have been created allowing us to infer the probability that a genetic variant is pathogenic or not. Unfortunately, different prediction algorithms use different information and each has its own strength and weakness. Since it has been suggested that investigators should use predictions from multiple algorithms instead of relying on a single one, Liu et al (2011) have developed dbNSFP (database for nonsynonymous SNPs functional predictions). It compiles prediction scores from four algorithms (SIFT, Polyphen2,LRT, and MutationTaster), along with a conservation score (PhyloP) and other related information, for every potential non synonymous variant in the human genome.

\section{Conclusion}

Despite the progress in knowledge of the mechanisms, risk factors, and management of SCD, it remains being a major public-health problem. One of the challenges is the accurate identification of the person at risk, especially in younger people where the sudden death is most of the times the first manifestation of the disease. Multimarker SCD risk scores including demographic, clinical and genetic variables should improve the identification of persons at risk (Adabag et al., 2010).

Although there are other processes affecting the electrical cardiac systole, pathologies considered in this chapter are the familiar diseases with a clear genetic inheritance in which genetic diagnosis has a great relevance.

Capturing strategies followed by NGS allowed us to accurately detect arrhythmogenic disease causing mutations in a fast and cost-efficient manner that will be suitable for daily clinical practice of genetic testing. Nevertheless, we cannot forget the need to use additional strategies proving their disease causality.

Additional benefits of great value in these genetically and phenotypically heterogeneous disease are: 1) the ability to detect both, known mutations and novel mutations, 2) the possibility of screening only selected gene exons or all exons in the human genome, and finally 3) the ability to detect individuals with multiple mutations.

\section{Acknowledgments}

Supported by grant PI10/00851 and grant EMER 07/018 from the Spanish Health Institute ISCIII to MB.

\section{References}

Adabag, A.S.; Luepker, R.V.; Roger, V.L.; Gersh, B.J (2010). Sudden cardiac death: epidemiology and risk factors. Nat Rev Cardiol.,7(4), pp. 216-225. ISSN: 1759-5002

Albert, TJ.; Molla, MN.; Muzny, DM.; Nazareth, L.; Wheeler, D.; Song, X.; Richmond, TA.; Middle, CM.; Rodesch, MJ.; Packard, CJ.; Weinstock, GM.\& Gibbs, RA.(2007). Direct selection of human genomic loci by microarray hybridization. Nat Methods, Vol. 4, No. 11, pp. 903-905, ISSN 1548-7091 
Bamshad, MJ.; Ng SB.; Bigham, AW.; Tabor, HK.; Emond, MJ.; Nickerson, DA. \& Shendure J. (2011). Exome sequencing as a tool for Mendelian disease gene discovery. Nat Rev Genet. Vol. 12, No. 11, pp.745-755, ISSN 1471-0056

Bazzet, H. (1920). An analysis of the time relationship of electrocardiograms. Heart, Vol. 7, pp. 53-370.

Campuzano, O.; Beltrán-Alvarez, P.; Iglesias, A.; Scornik, F.; Pérez, G. \& Brugada, R. (2010). Genetics and cardiac channelopathies. Genet Med. Vol. 12, No. 5, pp.260-267, ISSN 1098-3600

Coumel, P.; Fidelle, J.; Lucet, V.; Attuel, P. \& Bouvrain, Y. (1978). Catecholamine-induced severe ventricular arrhythmias with Adams-Stokes syndrome in children: report of four cases. Br Heart J, Vol. 40(suppl), pp. 28-37, ISSN 0007-0769

Eid, J.; Fehr, A.; Gray, J.; Luong, K.; Lyle, J.; Otto, G.; Peluso, P.; Rank, D.; Baybayan, P.; Bettman, B.; Bibillo, A.; Bjornson, K.; Chaudhuri, B.; Christians, F.; Cicero, R.; Clark, S.; Dalal, R.; Dewinter, A.; Dixon, J.; Foquet, M.; Gaertner, A.; Hardenbol, P.; Heiner, C.; Hester, K.; Holden, D.; Kearns, G.; Kong, X.; Kuse, R.; Lacroix, Y.; Lin, S.; Lundquist, P.; Ma, C.; Marks, P.; Maxham, M.; Murphy, D.; Park, I.; Pham, T.; Phillips, M.; Roy, J.; Sebra, R.; Shen, G.; Sorenson, J.; Tomaney, A.; Travers, K.; Trulson, M.; Vieceli, J.; Wegener, J.; Wu, D.; Yang, A.; Zaccarin, D.; Zhao, P.; Zhong, F.; Korlach, J. \& Turner, S. (2009). Real-time DNA sequencing from single polymerase molecules. Science, Vol. 323, No. 5910, pp. 133-138, ISSN 0036-8075

Fedurco, M.; Romieu, A.; Williams, S.; Lawrence, I. \& Turcatti, G. (2006). BTA, a novel reagent for DNA attachment on glass and efficient generation of solid-phase amplified DNA colonies. Nucleic Acids Res, Vol. 34, No. 3, e22, ISNN 0305-1048

Fuster, O.R., Walsh, Poole-Wilson, KingIII, Roberts,Nash, Prystowsky. (2008). Hurst's the heart. 12th edition. McGraw Hill.

Glenn, TC. (2011). Field guide to next-generation DNA sequencers. Mol Ecol Resour, Vol. 11, No. 5, pp. 759-769, ISSN 1755-098X

Gnirke, A.; Melnikov, A.; Maguire, J.; Rogov, P.; LeProust, EM.; Brockman, W.; Fennell, T.; Giannoukos, G.; Fisher, S.; Russ, C.; Gabriel, S.; Jaffe, DB.; Lander, ES.\& Nusbaum, C. (2009). Solution hybrid selection with ultra-long oligonucleotides for massively parallel targeted sequencing. Nat Biotechnol, Vol. 27, No. 2, pp. 182-189, ISSN 10870156

Gussak, I.; Brugada, P.; Brugada, J.; Wright, R.S.; Kopecky, S.L.; Chaitman, B.R. \& Bjerregaard, P. (2000). Idiopathic short QT interval: a new clinical syndrome? Cardiology, Vol. 94, No. 2, pp. 99-102, ISSN 0008-6312

Harris, TD.; Buzby, PR.; Babcock, H.; Beer, E.; Bowers, J.; Braslavsky, I.; Causey, M.; Colonell, J.; Dimeo, J.; Efcavitch, JW.; Giladi, E.; Gill, J.; Healy, J.; Jarosz, M.; Lapen, D.; Moulton, K.; Quake, SR.; Steinmann, K.; Thayer, E.; Tyurina, A.; Ward, R.; Weiss, H. \& Xie, Z. (2008). Single-molecule DNA sequencing of a viral genome. Science, Vol. 320, No. 5872, pp. 106-109, ISSN 0036-8075

Hedley, P.L.; Jørgensen, P.; Schlamowitz, S.; Moolman-Smook, J.; Kanters, J.K.; Corfield, V.A. \& Christiansen, M. (2009). The genetic basis of Brugada syndrome: a mutation update. Hum Mutat, Vol. 30, No. 9, pp. 1256-1266, ISSN 1059-7794

Hedley, P.L.; Jørgensen, P.; Schlamowitz, S.; Wangari, R.; Moolman-Smook, J.; Brink, P.A.; Kanters, J.K.; Corfield, V.A. \& Christiansen, M. (2009). The genetic basis of long QT 
and short QT syndromes: a mutation update. Hum Mutat, Vol. 30, No. 11, pp. 1486511, ISSN 1059-7794

Hodges, E.; Xuan, Z.; Balija, V.; Kramer, M.; Molla, MN.; Smith, SW.; Middle, CM.; Rodesch, MJ.; Albert, TJ.; Hannon, GJ. \& McCombie, WR. (2007). Genome-wide in situ exon capture for selective resequencing. Nat Genet. Vol. 39, No. 12, pp. 1522-1527, ISSN 1061-4036

Johansson, H.; Isaksson, M.; Sörqvist, EF.; Roos, F.; Stenberg, J.; Sjöblom, T.; Botling, J.; Micke, P.; Edlund, K.; Fredriksson, S.; Kultima, HG.; Ericsson, O. \& Nilsson, M. (2011). Targeted resequencing of candidate genes using selector probes. Nucleic Acids Res, Vol. 39, No. 2, e8, ISSN 0305-1048

Kapplinger, J.D.; Tester, D.J.; Salisbury, B.A.; Carr, J.L.; Harris-Kerr, C.; Pollevick, G.D.; Wilde, A.A. \& Ackerman, M.J. (2009). Spectrum and prevalence of mutations from the first 2,500 consecutive unrelated patients referred for the FAMILION long QT syndrome genetic test. Heart Rhythm., Vol. 6, No. 9, pp. 1297-1303, ISSN 1547-5271

Liu, X.; Jian, X. \& Boerwinkle, E. (2011). dbNSFP: A Lightweight Database of Human Nonsynonymous SNPs and Their Functional Predictions. Hum Mutat,.Vol. 32, No. 8, pp. 894-899, ISSN 1059-7794

Mamanova, L.; Coffey, AJ.; Scott, CE.; Kozarewa, I.; Turner, EH.; Kumar, A.; Howard, E.; Shendure, J. \& Turner, DJ. (2010). Target-enrichment strategies for next-generation sequencing. Nat Methods, Vol. 7, No. 2, pp. 111-118, ISSN 1548-7091

Margulies, M.; Egholm, M.; Altman, WE.; Attiya, S.; Bader, JS.; Bemben, LA.; Berka, J.; Braverman, MS.; Chen, YJ.; Chen, Z.; Dewell ,SB.; Du, L.; Fierro, JM.; Gomes, XV.; Godwin, BC.; He, W.; Helgesen, S.; Ho, CH.; Irzyk, GP.; Jando, SC.; Alenquer, ML.; Jarvie, TP.; Jirage, KB.; Kim, JB.; Knight, JR.; Lanza,JJR.; Leamon, JH.; Lefkowitz, SM.; Lei, M.; Li, J.; Lohman, KL.; Lu, H.; Makhijani, VB.; McDade, KE.; McKenna, MP.; Myers, EW.; Nickerson, E.; Nobile, JR.; Plant, R.; Puc, BP.; Ronan, MT.; Roth, GT.; Sarkis, GJ.; Simons, JF.; Simpson, JW.; Srinivasan, M.; Tartaro, KR.; Tomasz, A.; Vogt, KA.; Volkmer, GA.; Wang, SH.; Wang, Y.; Weiner, MP.; Yu, P.; Begley, RF. \& Rothberg, JM. (2005). Genome sequencing in microfabricated high-density picolitre reactors. Nature, Vol. 437, No. 7057, pp. 376-380, ISSN 0028-0836

Meder, B.; Haas, J.; Keller, A.; Heid, C.; Just, S.; Borries, A.; Boisguerin, V.; ScharfenbergerSchmeer, M.; Stähler, P.; Beier, M.; Weichenhan, D.; Strom, T.M.; Pfeufer, A.; Korn, B.; Katus, H.A.; Rottbauer, W. (2011). Targeted next-generation sequencing for the molecular genetic diagnostics of cardiomyopathies. Circ Cardiovasc Genet., 4(2), pp.110-122. ISSN: 1942-325X

Metzker, ML. (2010). Sequencing technologies - the next generation. Nat Rev Genet, Vol.11, No.1, pp. 31-46, ISSN 1471-0056

Napolitano, C.; Priori, S.G.; Schwartz, P.J.; Bloise, R.; Ronchetti, E.; Nastoli, J.; Bottelli, G.; Cerrone, M. \& Leonardi, S. (2005). Genetic testing in the long QT syndrome: development and validation of an efficient approach to genotyping in clinical practice. JAMA, Vol. 294, No. 23, pp. 2975-2980, ISSN 0098-7484

Ng, SB.; Turner, EH.; Robertson, PD.; Flygare, SD.; Bigham, AW.; Lee, C.; Shaffer, T.; Wong, M.; Bhattacharjee, A.; Eichler, EE.; Bamshad, M.; Nickerson, DA.\& Shendure, J. (2009). Targeted capture and massively parallel sequencing of 12 human exomes. Nature, Vol. 461, No. 7261, pp. 272-276, ISSN 0028-0836 
Priori, S.G.; Napolitano C. \& Schwartz P.J. (1999). Low penetrance in the long-QT syndrome: clinical impact. Circulation, Vol. 99, No. 4, pp. 529-533, ISSN 0009-7322

Priori, S.G.; Napolitano, C.; Gasparini, M.; Pappone, C.; Della Bella, P.; Giordano, U.; Bloise, R.; Giustetto, C.; De Nardis, R.; Grillo, M.; Ronchetti, E.; Faggiano, G.\& Nastoli, J. (2002). Natural history of Brugada syndrome: insights for risk stratification and management. Circulation. Vol. 105, pp. 1342-1347, ISSN 0009-7322

Priori, S.G.; Napolitano, C.; Memmi, M.; Colombi, B.; Drago, F.; Gasparini, M.; DeSimone, L.; Coltorti, F.; Bloise, R.; Keegan, R.; Cruz Filho, F.E.; Vignati, G.; Benatar, A. \& DeLogu, A. (2002). Clinical and molecular characterization of patients with catecholaminergic polymorphic ventricular tachycardia. Circulation. Vol. 106, pp. 69 -74, ISSN 0009-7322

Priori, S.G.; Schwartz, P.J.; Napolitano, C.; Bloise, R.; Ronchetti, E.; Grillo, M.; Vicentini, A.; Spazzolini, C.; Nastoli, J.; Bottelli, G.; Folli, R. \& Cappelletti, D. (2003). Risk stratification in the long-QT syndrome. N Engl J Med. Vol. 348, pp. 1866-1874, ISSN 0028-4793

Rogan, P.K.; Svojanovsky, S. \& Leeder, J.S. (2003). Information theory-based analysis of CYP2C19, CYP2D6 and CYP3A5 splicing mutations. Pharmacogenetics, Vol. 13, pp. 207-218, ISSN 0960-314X

Rothberg, JM.; Hinz, W.; Rearick, TM.; Schultz, J.; Mileski, W.; Davey, M.; Leamon, JH.; Johnson, K.; Milgrew, MJ.; Edwards, M.; Hoon, J.; Simons, JF.; Marran, D.; Myers, JW.; Davidson, JF.; Branting, A.; Nobile, JR.; Puc, BP.; Light, D.; Clark, TA.; Huber, M.; Branciforte, JT.; Stoner, IB.; Cawley, SE.; Lyons, M.; Fu, Y.; Homer, N.; Sedova, M.; Miao, X.; Reed, B.; Sabina, J.; Feierstein, E.; Schorn, M.; Alanjary, M.; Dimalanta, E.; Dressman, D.; Kasinskas, R.; Sokolsky, T.; Fidanza, JA.; Namsaraev, E.; McKernan, KJ.; Williams, A.; Roth, GT. \& Bustillo, J. (2011). An integrated semiconductor device enabling non-optical genome sequencing. Nature. Vol. 475, No. 7356, pp.348-352, ISSN 0028-0836

Schimpf, R.; Borggrefe M. \& Wolpert, C. (2008). Clinical and molecular genetics of the short QT syndrome. Curr Opin Cardiol, Vol. 23, No. 3, pp. 192-198, ISSN 0268-4705

Schott, J.J.; Alshinawi, C.; Kyndt, F.; Probst, V.; Hoorntje, T.M.; Hulsbeek, M.; Wilde, A.A.; Escande, D.; Mannens, M.M. \& Le Marec, H. (1999). Cardiac conduction defects associate with mutations in SCN5A. Nat Genet, Vol. 23, No.1, pp. 20-21, ISSN 10614036

Shendure, J.\& Ji H. (2008). Next-generation DNA sequencing.Nat Biotechnol, Vol. 26, No. 10, pp1135-1145, ISSN 1087-0156

Tewhey, R.; Warner, JB.; Nakano, M.; Libby, B.; Medkova, M.; David, PH.; Kotsopoulos, SK.; Samuels, ML.; Hutchison, JB.; Larson, JW.; Topol, EJ.; Weiner, MP.; Harismendy, O.; Olson, J.; Link, DR. \& Frazer KA. (2010). Microdroplet-based PCR enrichment for large-scale targeted sequencing. Nat Biotechnol. Vol. 27, No. 11pp. 1025-1031, ISSN 1087-0156

Turcatti, G.; Romieu, A.; Fedurco, M. \& Tairi, AP. (2008). A new class of cleavable fluorescent nucleotides: synthesis and optimization as reversible terminators for DNA sequencing by synthesis. Nucleic Acids Res, Vol. 36, No. 4, e25, ISSN 0305-1048

Turner, EH.; Ng, SB.; Nickerson, DA. \& Shendure J. (2009). Methods for genomic partitioning. Annu Rev Genomics Hum Genet, Vol. 10, pp. 263-284, ISSN 1527-8204 
Valouev, A.; Ichikawa, J.; Tonthat, T.; Stuart, J.; Ranade, S.; Peckham, H.; Zeng, K.; Malek, JA.; Costa, G.; McKernan, K.; Sidow, A.; Fire, A. \& Johnson, SM. (2008). A highresolution.; nucleosome position map of $\mathrm{C}$. elegans reveals a lack of universal sequence-dictated positioning. Genome Res, Vol. 18, No. 7, pp. 1051-1063, ISSN 10889051

Vincent, G.M.; Timothy, K.W.; Leppert, M. \& Keating, M. (1992). The spectrum of symptoms and QT intervals in carriers of the gene for the long-QT syndrome. $N$ Engl J Med, Vol. 327, No. 12, pp. 846-852, ISSN 0028-4793

Voelkerding, KV.; Dames, S. \& Durtschi, J.D. (2010). Next Generation Sequencing for Clinical Diagnostics-Principles and Application to Targeted Resequencing for Hypertrophic Cardiomyopathy. Journal of Molecular Diagnostics Vol. 12, No.5, pp. 539-551, ISSN 1525-1578

Yeager, M.; Xiao, N.; Hayes, RB.; Bouffard, P.; Desany, B.; Burdett, L.; Orr, N.; Matthews, C.; Qi, L.; Crenshaw, A.; Markovic ,Z.; Fredrikson, KM.; Jacobs, KB.; Amundadottir, L.; Jarvie, TP.; Hunter, DJ.; Hoover, R.; Thomas, G.; Harkins, TT.\& Chanock SJ. (2008). Comprehensive resequence analysis of a $136 \mathrm{~kb}$ region of human chromosome 8q24 associated with prostate and colon cancers. Hum Genet, Vol. 124, No. 2, pp. 161-170, ISSN 0340-6717

Ylänen, K.; Poutanen, T.; Hiippala, A.; Swan, H.; Korppi, M. (2010). Catecholaminergic Polymorphic ventricular tachycardia. Eur J Pediatr., 169(5), pp. 535-542. ISSN: 03406199

Zareba, W. \& Cygankiewicz, I. (2008). Long QT syndrome and short QT syndrome. Prog Cardiovasc Dis, Vol. 51, No.3, pp. 264-278, ISSN 0033-0620

Zipes, D.P.; Camm, A.J.; Borggrefe, M.; Buxton, A.E.; Chaitman, B.; Fromer, M.; Gregoratos, G.; Klein, G.; Moss, A.J.; Myerburg, R.J.; Priori, S.G.; Quinones, M.A.; Roden, D.M.; Silka, M.J.; Tracy, C.; Smith, S.C. Jr, Jacobs, A.K.; Adams, C.D.; Antman, E.M.; Anderson, J.L.; Hunt, S.A.; Halperin, J.L.; Nishimura, R.; Ornato, J.P.; Page, R.L.; Riegel, B.; Priori, S.G.; Blanc, J.J.; Budaj, A.; Camm, A.J.; Dean, V.; Deckers, J.W.; Despres, C.; Dickstein, K.; Lekakis, J.; McGregor, K.; Metra, M.; Morais, J.; Osterspey, A.; Tamargo, J.L.; Zamorano, J.L.; American College of Cardiology ; American Heart Association Task Force; \& European Society of Cardiology Committee for Practice Guidelines. (2006). ACC/ AHA/ESC 2006 Guidelines for management of patients with ventricular arrhythmias and the prevention of sudden cardiac death: a report of the American College of Cardiology/American Heart Association Task Force and the European Society of Cardiology Committee for Practice Guidelines (Writing Committee to Develop Guidelines for Management of Patients With Ventricular Arrhythmias and the Prevention of Sudden Cardiac Death). J Am Coll Cardiol, Vol. 48, e247- e346, ISSN 0735-1097 


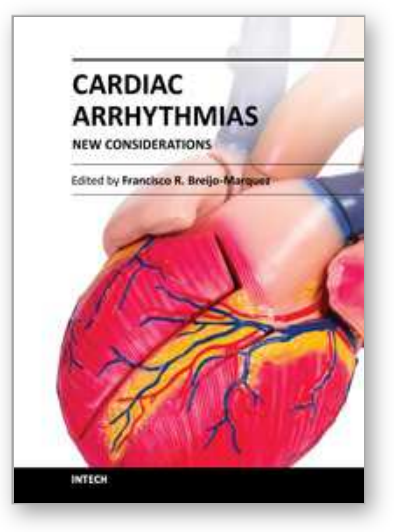

\author{
Cardiac Arrhythmias - New Considerations \\ Edited by Prof. Francisco R. Breijo-Marquez
}

ISBN 978-953-51-0126-0

Hard cover, 534 pages

Publisher InTech

Published online 29, February, 2012

Published in print edition February, 2012

The most intimate mechanisms of cardiac arrhythmias are still quite unknown to scientists. Genetic studies on ionic alterations, the electrocardiographic features of cardiac rhythm and an arsenal of diagnostic tests have done more in the last five years than in all the history of cardiology. Similarly, therapy to prevent or cure such diseases is growing rapidly day by day. In this book the reader will be able to see with brighter light some of these intimate mechanisms of production, as well as cutting-edge therapies to date. Genetic studies, electrophysiological and electrocardiographyc features, ion channel alterations, heart diseases still unknown , and even the relationship between the psychic sphere and the heart have been exposed in this book. It deserves to be read!

\title{
How to reference
}

In order to correctly reference this scholarly work, feel free to copy and paste the following:

Maria Brion, Beatriz Sobrino, Alejandro Blanco-Verea, Montserrat Santori, Rocio Gil and Angel Carracedo (2012). Novel Genomic Approach to the Arrhytmogenic Sudden Cardiac Death, Cardiac Arrhythmias - New Considerations, Prof. Francisco R. Breijo-Marquez (Ed.), ISBN: 978-953-51-0126-0, InTech, Available from: http://www.intechopen.com/books/cardiac-arrhythmias-new-considerations/novel-genomic-aproach-to-thearrhitmogenic-sudden-cardiac-death-

\section{INTECH}

open science | open minds

\author{
InTech Europe \\ University Campus STeP Ri \\ Slavka Krautzeka 83/A \\ 51000 Rijeka, Croatia \\ Phone: +385 (51) 770447 \\ Fax: +385 (51) 686166 \\ www.intechopen.com
}

\author{
InTech China \\ Unit 405, Office Block, Hotel Equatorial Shanghai \\ No.65, Yan An Road (West), Shanghai, 200040, China \\ 中国上海市延安西路65号上海国际贵都大饭店办公楼405单元 \\ Phone: +86-21-62489820 \\ Fax: +86-21-62489821
}


(C) 2012 The Author(s). Licensee IntechOpen. This is an open access article distributed under the terms of the Creative Commons Attribution 3.0 License, which permits unrestricted use, distribution, and reproduction in any medium, provided the original work is properly cited. 